\title{
Afghanistan Donor Conference: \\ Testing Time for the Afghan-International Partnership \\ Donor fatigue has not set in, but security commitments continue to fall short
}

Jointly Prepared by CARE and Center on International Cooperation (New York University)
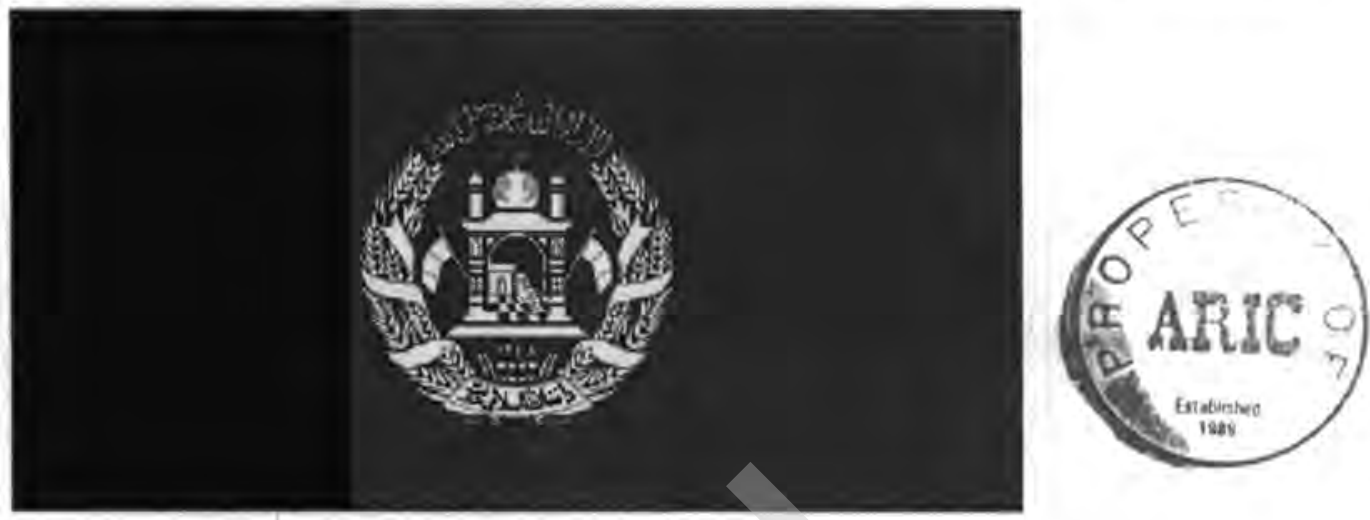

At the International Conference on Afghanistan in Berlin on March 31-April 1, the Afghan government set the agenda and confronted richer and more powerful governments with what it needs to succeed. It did so even though many donor governments, including the German hosts, initially resisted the Afghan proposals. Those governments promised not just to stay involved but actually increase the level of funding for this year and to continue in succeeding years. So far, however, the donor governments have failed to provide the few thousand additional troops needed to help Kabul reassert its authority and provide security in the provinces. Without this aid, through the NATO-led International Security Assistance Force, insecurity will prevent the government from using properly the money now pledged for reconstruction.

Kabul presented a detailed research report arguing that building a secure Afghanistan would require a plan costing about $\$ 28$ billion over the next seven years. Though Afghanistan still lacks the research capacity to carry out such a project alone, the government used its political standing to leverage aid from international development banks and the UN in the service of its sovereign goals. These institutions provided over a hundred experts to collaborate with the Afghans in producing the report. As a result, donors, who usually confront war-torn countries with programs dictated by their own domestic political realities, were forced to confront the genuine requirements of success. The whole international community may therefore benefit from the Afghan government's assertion of ownership.

While donors did not and could not fund the entire seven-year program, they pledged $\$ 8.2$ billion, including slightly more than full funding, $\$ 4.5$ billion, for the current Afghan fiscal year. Several countries made multi-year pledges, amounting to $\$ 2.4$ billion 
for the second year and $\$ 1.4$ billion for the third. The third year does not yet include the US funding, which may raise it by another $\$ 2$ billion, if Washington interprets literally its pledge to "stay the course. (See table 1.)

The final document of the conference included not only the international community's pledge to assist Afghanistan, but also the Afghan government's pledge to use assistance in a transparent and accountable way. The Afghan government issued a demanding work plan, covering the economic, political, and security areas, simultaneously with the Berlin declaration. While there is no explicit conditionality, all understand that delivery of the donors' pledges will be conditional on performance of the work plan.

Hence, as Kevin Henry, CARE Advocacy Director, said, "The coming year heralds a testing time for the partnership between Afghanistan and its donors: The international community must deliver on its funding pledges but the Afghan government must build its capacity to use those resources effectively and transparently."

If both sides live up to their promises, there can be hope that this will lay the foundations for greater commitment to Afghanistan's reconstruction in the longer-term. 'This year will provide a benchmark. If both sides deliver, then there is a better chance that donors will increase their engagement for subsequent years,' said Barnett Rubin of the Center on International Cooperation (CIC) at New York University.

Long-term commitment, however, needs strengthening. Only $\$ 1.4$ billion in firm commitments - just $36 \%$ of the requested amount - have been made for the third year. Donors must increase this commitment in order to meet the roughly $\$ 4$ billion in annual funding deemed necessary by Afghanistan to achieve its reconstruction goals. Without long-term commitment it will be very difficult for the Afghan government to undertake some of the major reconstruction projects contained in its seven-year plan. While several donors made new multi-year pledges in Bonn, many continue to provide funding on only a year-to-year basis.

\section{SECURITY}

The importance of addressing the current security problems within Afghanistan was also given significant attention at the Berlin conference. Hamid Karzai, Afghanistan's president, highlighted the need to address the interrelated problems posed by warlordism, terrorism, and the escalating opium trade.

Urgent progress in disarmament is especially important in view of the upcoming elections, planned for September 2004. Full implementation of an agreement reached recently to canton heavy weapons and disarms 40 percent of the fighters before the elections would be a positive indicator for future progress in Afghanistan. 
NATO's decision to expand ISAF's (International Security Assistance Force) presence outside Kabul is also to be welcomed. But no NATO members offered new troop contributions at the Berlin conference.

Regarding the drugs trade, President Karzai noted that, if left unchecked, it could threaten the very existence of the Afghan state. In Berlin Afghanistan signed an agreement with neighboring countries on cooperation to tackle the growing drugs trade. A future meeting in Kabul will aim to provide more concrete content to this agreement.

\section{Table 1}

Summary of pledges from Berlin conference

\section{Summary of pledges}

\begin{tabular}{|l|l|l|l|}
\hline Year & Pledge & SAF Tanget* & $\%$ of Target \\
\hline 1383 & $\$ 4.5 \mathrm{~b}$ & $\$ 4.4 \mathrm{~b}$ & $103 \%$ \\
\hline 1384 & $\$ 2.4 \mathrm{~b}$ & $\$ 3.7 \mathrm{~b}$ & $65 \%$ \\
\hline 1385 & $\$ 1.4 \mathrm{~b}$ & $\$ 3.8 \mathrm{~b}$ & $36 \%$ \\
\hline Total & $\$ 8.2 \mathrm{~b}$ & $\$ 11.9 \mathrm{~b}$ & $70 \%$ \\
\hline
\end{tabular}

Nose: does not include future US contribution for 1385 onwards -SAF: Securing Afghanistan's Future - Government/International Agency Report. avallable at Government website at www. af

For up to date information on post-conflict reconstruction and socioeconomic development in Afghanistan visit the Development Gateway's Afghanistan Reconstruction page at: http://www.developmentgateway.org/afghanistan 
Resources Available to Finance Afghanistan Reconstruction

(Based on information provided by donors to Ministry of Finance as at 31 March 2004, 2200)

\begin{tabular}{|c|c|c|c|c|c|c|c|c|c|}
\hline \multirow{3}{*}{ Donor } & \multicolumn{9}{|c|}{ RESOURCES THROUGH GRANT PLEDGES 4Q1380-1387 (Jan 2002 - March 2009) } \\
\hline & $4 Q 80+1381$ & 1382 & 1383 & 1384 & 1385 & 3-year Total & 1386 & 1387 & Total \\
\hline & Jan'02-Mar'03 & Mar'03-Mar'04 & Mar'04-Mar'05 & $2005-06$ & $2006-07$ & Mar '04-Mar'07 & $2007-08$ & $2008-09$ & Jan'02-Mar'09 \\
\hline Aga Khan & 25.0 & 25.0 & 25.0 & & & 25.0 & & & 75.0 \\
\hline$A D B$ & 25.0 & 25.0 & 25.0 & 10.0 & 10.0 & 45.0 & 10.0 & 10.0 & 115.0 \\
\hline Australia & 15.0 & 5.3 & 13.3 & & & 13.3 & & & 33.6 \\
\hline Austria & 7niti & 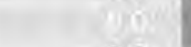 & 2.4 & 1.2 & & 3.6 & & & 3.6 \\
\hline Belgium & 11.7 & 6.0 & 4.3 & 5.6 & 6.2 & 16.1 & & & 33.8 \\
\hline Canada & 83.0 & 95.0 & 75.2 & 75.0 & 45.0 & 195.2 & 37.5 & 30.0 & 440.7 \\
\hline China & 27.0 & 20.0 & 15.0 & 13.0 & & 28.0 & & & 75.0 \\
\hline Denmark & 28.0 & 28.2 & 27.8 & 25.8 & 20.2 & 73.8 & & & 130.0 \\
\hline EC & 218.4 & 292.1 & 294.0 & 240.0 & 240.0 & 774.0 & & & $1,284.5$ \\
\hline $\mathrm{ECHO}$ & 73.5 & 63.3 & 0.0 & -1 & & . & & & 136.8 \\
\hline Finland & 10.0 & 11.5 & 13.0 & 12.0 & 12.0 & 37.0 & 12.0 & & 70.5 \\
\hline France & 32.0 & 30.2 & 37.2 & & & 37.2 & & & 99.4 \\
\hline Germany & 142.0 & 107.5 & 96.0 & 96.0 & 96.0 & 288.0 & 96.0 & 96.0 & 729.5 \\
\hline Greece & & & 3.6 & & & 3.6 & & & 3.6 \\
\hline India & 40.0 & 60.0 & 90.0 & 74.0 & 60.0 & 224.0 & 40.0 & 36.0 & 400.0 \\
\hline Iran & 50.0 & 50.0 & 54.0 & 50.0 & 50.0 & 154.0 & & & 254.0 \\
\hline Ireland & 4.0 & 5.0 & 6.9 & 3.0 & & 9.9 & & & 18.9 \\
\hline Italy & 43.0 & 52.8 & 56.0 & 56.0 & 56.0 & 168.0 & & & 263.8 \\
\hline Japan & 357.8 & 142.2 & 200.0 & 200.0 & & 400.0 & & & 900.0 \\
\hline Korea (Rep of) & 10.0 & 15.0 & 20.0 & & & 20.0 & & & 45.0 \\
\hline Kuwait & 15.0 & 30.0 & 00 & & & & & & 45.0 \\
\hline Luxembourg & 5.0 & 1.0 & 1.2 & & & 1.2 & & & 7.2 \\
\hline Netherlands & 100.5 & 65.3 & 42.0 & 42.0 & 36.0 & 120.0 & & & 285.8 \\
\hline New Zealand & $5=$ & afo & 3.3 & & & 3.3 & & & 3.3 \\
\hline Norway & 40.0 & 53.0 & 43.0 & 39.0 & 39.0 & 121.0 & 39.0 & & 253.0 \\
\hline Oman & 3.0 & 3.0 & 0.0 & & & 0.8 & & & 6.0 \\
\hline Pakistan & 50.0 & 20.0 & 10.0 & 15.0 & 10.0 & 35.0 & & & 105.0 \\
\hline Poland & & $6 \sqrt{n}$ & 0.1 & & & 0.1 & & & 0.1 \\
\hline Portugal & & & 1.2 & & & 1.2 & & & 1.2 \\
\hline Qatar & 20.0 & & 0.0 & & & · & & & 20.0 \\
\hline Russian Fed. & 30.0 & 30.0 & 0.0 & & & 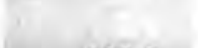 & & & 60.0 \\
\hline Saudi Arabia & 35.0 & 35.0 & 160.0 & & & 160.0 & & & 230.0 \\
\hline Spain & 25.7 & 62.0 & 50.0 & 5.0 & 5.0 & 60.0 & & & 147.7 \\
\hline Sweden & 30.0 & 35.6 & 39.3 & 39.3 & $6 x$ & 78.6 & & & 144.2 \\
\hline Switzerland & 12.0 & 13.0 & 14.8 & 12.5 & 11.7 & 39.0 & & & 64.0 \\
\hline Turkey & 2.2 & 2.0 & 3.0 & 1.0 & 1.0 & 5.0 & & & 9.2 \\
\hline UAE & 36.0 & & 0.0 & & & & & & 36.0 \\
\hline United Kingdom & 137.8 & 144.0 & 215.9 & 215.9 & 137.3 & 569.1 & & & 850.9 \\
\hline UN Agencies & & - & & - & - & - & - & - & - \\
\hline USA & 836.3 & $1,300.0$ & $2,300.0$ & 600.0 & & $2,900.0$ & & & $5,036.3$ \\
\hline World Bank & 103.3 & 160.0 & 85.0 & 105.0 & 100.0 & 290.0 & & & 553.3 \\
\hline Other & 15.1 & 11.5 & 0.0 & & & 00 & & & 26.5 \\
\hline \multirow[t]{2}{*}{ Total Grants } & $2,692.3$ & $2,999.5$ & $4,027.5$ & $1,936.3$ & 935.3 & $6,899.2$ & 234.5 & 172.0 & $12,997.5$ \\
\hline & \multicolumn{9}{|c|}{ RESOURCES THROUGH LOAN FINANCING 4Q1380-1387 (Jan 2002 - March 2009) } \\
\hline ADB & 150.0 & 150.0 & 180.0 & 190.0 & 190.0 & 560.0 & 190.0 & 190.0 & $1,240.0$ \\
\hline China & (20) & & 25.0 & 25.0 & 25.0 & 75.0 & & & 75.0 \\
\hline Islamic Dev Bank & 10.0 & & 40.0 & 20.0 & & 60.0 & & & 70.0 \\
\hline World Bank & 108.0 & 200.0 & 200.0 & 205.0 & 205.0 & 610.0 & & & 918.0 \\
\hline Total Loans & 268.0 & 350.0 & 445.0 & 440.0 & 420.0 & $1,305.0$ & 190.0 & 190.0 & $2,303.0$ \\
\hline \begin{tabular}{|l|} 
Total Resources \\
(Grants + Loans)
\end{tabular} & $2,960.3$ & $3,349.5$ & $4,472.5$ & $2,376.3$ & $1,355.3$ & $8,204.2$ & 424.5 & 362.0 & $15,300.5$ \\
\hline
\end{tabular}

1 Loan financing is highly concessional and often includes grant components.

2 Ineluded in the USA pledge is $\$ 1.2$ billion that requires approval by Congress. Half of this amount is reflected in 1383 and half in 1384

3 Many grants are made in currencies other than US dollars. The figures shown here are approximations, using current exhange rates. 


\section{Pledge Session Outcome (1 April 2004)}

\section{Key Points}

- Donor pledges stand at $\$ 4.5 \mathrm{~b}$ for 1383 , slightly exceeding the 1383 target of $\$ 4.4 \mathrm{~b}$ $102 \%$ of 1383 target.

- Of the 3 year target from 1383 through 1385 of $\$ 11.9 \mathrm{~m}$, donor pledges of $\$ 8.2 \mathrm{~m}$, or $69 \%$ of the requirement have been received.

\section{Summary of pledges}

\begin{tabular}{|l|l|l|l|}
\hline Year & Pledge & SAF Target & \% of Target \\
\hline 1383 & $\$ 4.5 \mathrm{~b}$ & $\$ 4.4 \mathrm{~b}$ & $102 \%$ \\
\hline 1384 & $\$ 2.4 \mathrm{~b}$ & $\$ 3.7 \mathrm{~b}$ & $64 \%$ \\
\hline 1385 & $\$ 1.4 \mathrm{~b}$ & $\$ 3.8 \mathrm{~b}$ & $36 \%$ \\
\hline Total & $\$ 8.2 \mathrm{~b}$ & $\$ 11.9 \mathrm{~b}$ & $69 \%$ \\
\hline
\end{tabular}

Note: does not include future US contribution for 1385 onwards

\section{Additional Information}

- Against a total requirement of $\$ 27.5 \mathrm{~b}$ over 7 years, the international community has contributed $\$ 8.2 \mathrm{~b}$ over the next 3 years.

The duration of pledges received from donors is as follows:

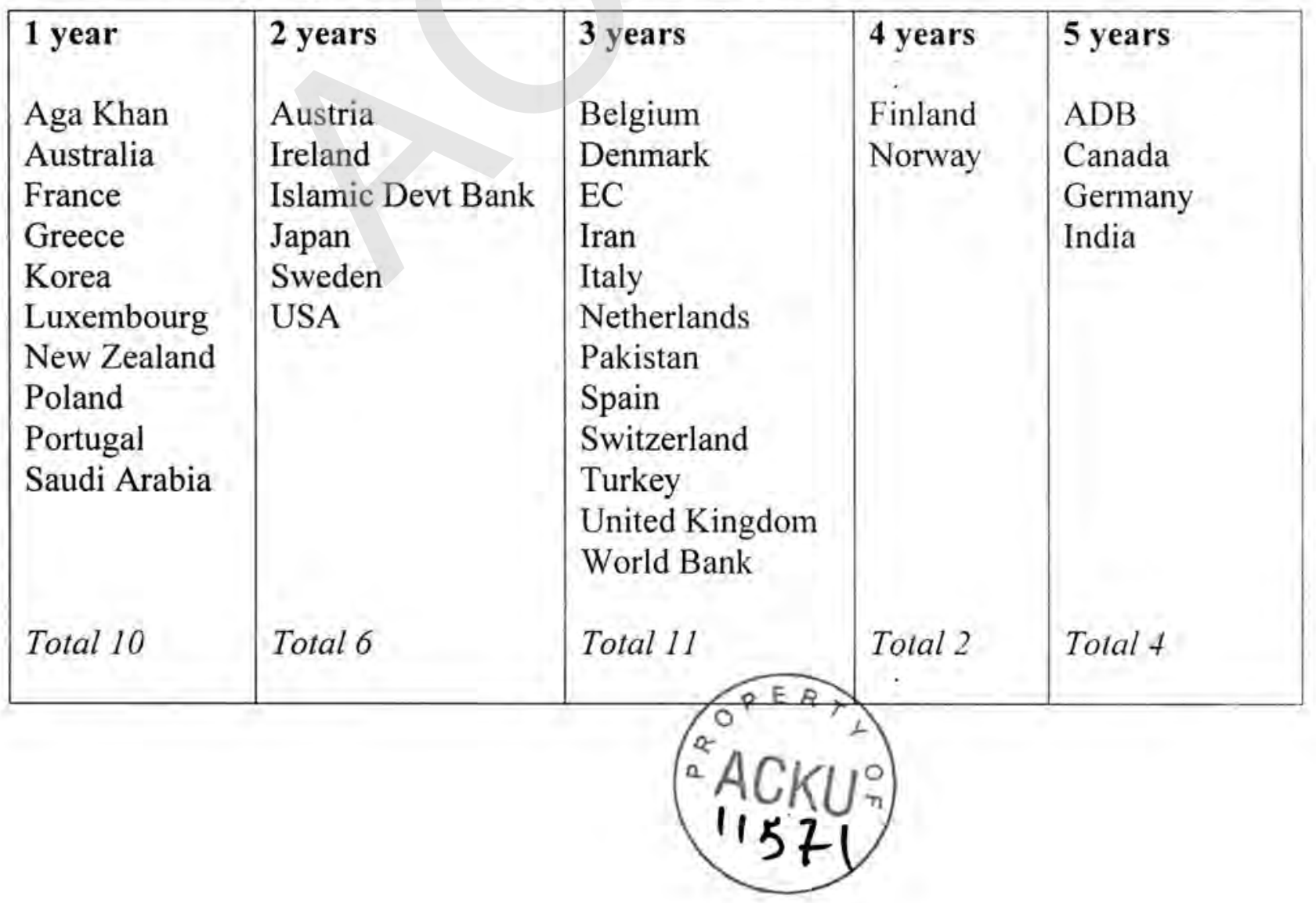

